\title{
Keterampilan literasi informasi sebagai upaya pencegahan hoaks mengenai informasi kesehatan di media sosial
}

\author{
Tine Silvana Rachmawati ${ }^{1}$, Merryam Agustine ${ }^{2}$ \\ 1Program Studi Perpustakaan dan Sains Informasi, Universitas Padjadjaran \\ Jl. Raya Bandung-Sumedang Km. 21, Jatinangor, Sumedang, Jawa Barat, 45363 \\ 2Program Studi Perpustakaan dan Sains Informasi, Universitas Widyatama \\ Jl. Cikutra No. 204 A, Sukapada, Cibeunying Kidul, Bandung, Jawa Barat, 40125 \\ E-mail: ${ }^{1}$ tine.silvana@unpad.ac.id, ${ }^{2}$ merryam.agustine@widyatama.ac.id
}

Received: July 2020 ; Accepted: May 2021 ; Published: June 2021

\begin{abstract}
People must know how identify and search for credible health information. This study aimed to determine how information literacy activities prevented the spread of health information hoaxes on social media. This study used a qualitative approach and case study research methods. The collect research data through observation, interviews with 15 interviewees, and literature study techniques. The study results found that people obtained health information literacy by utilizing social media that is used daily. First, people recognized when they needed information, meaning they already understood when to search for information and knew what information to seek. Second, people can find information was performed in various ways, such as choosing a mass media portal that was easy to use, searching for specific information by including keywords or hashtags. Third, people evaluate the information found by knowing who made the information. Who disseminates the information? Are social media accounts trustworthy? Does the skill match the required information? Fourth, people use the obtained information effectively. People only chose the information that was suitable for what they felt and needed. Conclusion this research is people that who use social media must have information literacy expertise in finding health information so that avoid hoax information widely circulating today.
\end{abstract}

Keywords: Health information; Information literacy; Social media; Hoax prevention

\begin{abstract}
Abstrak
Masyarakat harus mengetahui bagaimana cara mengidentifikasi dan mencari informasi kesehatan yang kredibel. Penelitian ini bertujuan untuk mengetahui bagaimana kegiatan literasi informasi sebagai salah satu upaya pecegahan hoaks terutama mengenai informasi kesehatan yang beredar di media sosial. Penelitian ini menggunakan pendekatan kualitatif dengan metode penelitian studi kasus. Teknik pengumpulan data menggunakan wawancara kepada 15 informan dan teknik dokumentasi. Berdasarkan hasil penelitian menemukan bahwa masyarakat memperoleh literasi informasi kesehatan dengan memanfaatkan media sosial yang digunakan sehari-hari. Pertama, masyarakat mengenali kapan informasi tersebut dibutuhkan. Hal ini memiliki makna bahwa masyarakat sudah memahami kapan harus mencari informasi dan mengetahui informasi apa yang akan dicari. Kedua, masyarakat dapat menemukan informasi yang dilakukan dalam berbagai cara antara lain memilih portal media massa yang mudah untuk digunakan dan mencari informasi secara spesifik dengan menyertakan kata kunci atau hashtag. Ketiga, masyarakat melakukan evaluasi informasi yang sudah ditemukan dengan mengetahui siapa pembuat informasi tersebut? Siapa yang menyebarkan informasi tersebut? Apakah akun media sosialnya terpercaya? Apakah kepakarannya sudah sesuai informasi yang dibutuhkan? Keempat, masyarakat menggunakan secara efektif informasi yang telah didapatkan. Masyarakat hanya memilih informasi yang sesuai peruntukan dengan apa yang dirasakan dan dibutuhkan. Simpulan penelitian adalah masyarakat yang menggunakan media sosial harus memiliki keahlian literasi informasi dalam menemukan informasi seputar kesehatan agar terhindar dari informasi hoaks yang banyak beredar saat ini.
\end{abstract}

Kata Kunci: Informasi kesehatan; Literasi informasi; Media sosial; Pencegahan hoaks 


\section{PENDAHULUAN}

Masyarakat di era informasi banyak menggunakan teknologi untuk mempermudah kehidupan. Hal ini membuat proses komunikasi berubah secara dramatis, seperti penggunaan komputer, ponsel, dan produk teknologi canggih lainnya. Selain itu, dunia didominasi teknologi yang menghubungkan semua kegiatan melalui internet. Internet membuat dunia sebagai sebuah tempat yang kecil. Masyarakat dapat mengetahui masa lalu dan masa kini dengan satu klik.

Sebagian orang berbagi informasi dengan bebas untuk memeriksa informasi tersebut, memperbaiki, dan menerbitkan kembali jika diperlukan. Masyarakat memiliki akses ke informasi secara gratis sehingga memungkinkan masyarakat untuk mempelajari lebih lanjut semua informasi yang telah didapatkan. Sejumlah besar informasi gratis dapat diperoleh dari Google, Wikipedia, Blog, LinkedIn, dan ratusan situs website lainnya.

Keterbukaan informasi akan membangun sebuah kepercayaan. Logikanya adalah bahwa semakin banyak seseorang berbagi maka semakin banyak kepercayaan yang dibangun. Dengan demikian, semakin banyak kepercayaan yang dibangun, maka banyak informasi yang dibagikan. Itulah gambaran mengenai era informasi, yang saat ini masyarakat jalani.

Era informasi mengubah aktivitas individu setiap hari dan membuat tugas yang membosankan berjalan lebih menyenangkan dan efisien. Era informasi adalah suatu periode di mana pola kerja, permainan, dan interaksi secara fundamental dipengaruhi sistem untuk memproses dan mendistribusikan informasi.
Meskipun di era informasi ada banyak aspek positif, namun ada juga banyak hal negatif, seperti bagaimana informasi yang tersedia tidak diatur dengan baik. Selain itu, masalah hukum terkait privasi dan masalah etika yang dihadapi pengguna komputer setiap hari. Era informasi diyakini banyak individu seperti yang dikembangkan sekarang akan terus maju dan berkembang selama bertahun-tahun yang akan datang.

Masyarakat dapat memiliki akses yang cepat menuju informasi yang dibutuhkan merupakan hal yang luar biasa, contohnya, perangkat Global Positioning System (GPS) dan ponsel dapat membantu mencapai tujuan yang tidak dikenal melalui satu kali klik. Masyarakat dapat menemukan tempat untuk makan, tempat untuk tinggal, dan untuk mendapatkan hiburan. Semua informasi ini berada di ujung jari. Masyarakat memanfaatkan teknologi ini sampai taraf tertentu dan menggunakan informasi untuk mendapatkan keuntungan.

Setiap hari, masyarakat menjumpai lautan informasi yang semakin besar dan beragam melalui website, media massa, media sosial, dan karya yang diterbitkan. Masyarakat dapat menemukan informasi dalam berbagai format, dari sumber yang tak terbatas. Kualitas informasi sangat bervariasi, di antara pilihan informasi yang tersedia. Biasanya, masyarakat memilih mengambil sumber yang otoritatif, terkini, dan andal di samping sumber yang bias, ketinggalan zaman, menyesatkan, atau bahkan salah. Selain itu, pencarian secara daring cenderung menghasilkan lebih banyak informasi sehingga masyarakat memiliki kebebasan untuk memilih informasi yang diinginkan.

Ketika suatu peristiwa terjadi, informasi seputar kejadian melewati 
serangkaian tahapan, di mana informasi akan berubah dalam berbagai jenis informasi. Hal ini dinamakan siklus informasi (information timeline). Fakta yang terungkap dan dilakukan diskusi, maka fakta berubah kaya dan seringkali lebih jelas. Informasi dalam suatu peristiwa biasanya dimulai dari saluran informal atau media massa yang terus meliput acara tersebut. Kemudian, sumber informasi ilmiah pun membahas peristiwa tersebut.

Teknologi informasi dan komunikasi yang terus tumbuh memunculkan era informasi digital yang membawa perubahan yang sebelumnya belum pernah diketahui. Salah satunya melalui media sosial yang memiliki kelebihan dan kekurangan. Media sosial memiliki kelebihan sebagai alat pengembangan informasi yang bersifat pengetahuan. Adapun media sosial memiliki kekurangan dalam banyaknya informasi yang tersedia membuat informasi yang ada bias dan bahkan salah.

Individu dan organisasi harus dapat memperoleh informasi secara spesifik dalam memenuhi kebutuhannya. Informasi yang beredar luas tidak semuanya memuat informasi yang benar. Ada informasi palsu yang dibuat dan disebarkan dengan mudah melalui platform website dan media sosial sehingga berdampak luas di dunia nyata.

Informasi palsu atau hoaks biasanya diterbitkan untuk memersuasi cara pandang seseorang, membantu kegiatan politik atau menyebabkan bias, dan informasi palsu dapat membuat sebuah bisnis penerbit daring untung. Informasi palsu dapat menipu orang melalui isinya yang meyakinkan, seperti situs website terpercaya, menggunakan identitas diri, dan portal website yang hampir sama dengan organisasi suatu berita terkemuka.

Informasi palsu bukanlah hal baru. Informasi palsu sebagai topik hangat sejak 2017. Biasanya, masyarakat untuk mendapatkan informasi yang akurat akan mencari berita dari sumber terpercaya, jurnalis, dan outlet media yang diharuskan mengikuti kode praktik penyebaran informasi. Di sisi lain, internet telah menyediakan sebuah cara yang baru untuk penerbitan berbagi informasi dan pengonsumsian informasi dan berita melalui peraturan atau standar editorial yang masih sedikit.

Masyarakat saat ini mendapatkan berita dari situs media sosial dan jaringan menggunakan internet dan seringkali sulit untuk mengatakan apakah berita atau informasi itu kredibel atau tidak. Informasi yang berlebih, dapat menyebabkan masyarakat kebingungan memahami penggunaan internet. Hal ini dapat berkontribusi pada peningkatan berita palsu atau berita bohong. Untuk itu, portal media sosial dapat memainkan peranan besar dalam peningkatan jangkauan penyebaran berita atau informasi palsu ini.

Informasi tumbuh cepat di masyarakat dan beraneka ragam. Pengguna dari berbagai kalangan, misalnya pria atau wanita, kaya atau miskin, dewasa atau anak membutuhkan informasi untuk kehidupan. Walaupun demikian, informasi yang diinginkan belum tentu merupakan informasi yang dibutuhkan (Naik \& Padmini, 2014). Oleh karena itu, literasi informasi adalah salah satu kompetensi kunci penting dalam menghadapi era informasi sekarang ini.

Masyarakat dalam menguasai lingkungan informasi dapat menggunakan literasi informasi. Literasi informasi dipandang sebagai salah satu strategi 
penting dalam mengurangi ketidakpastian, dasar pembelajaran sepanjang hayat, dan kunci pemberdayaan (Mackey \& Jacobson, 2014). Literasi informasi menggabungkan satu set keterampilan dan kemampuan yang masyarakat perlu lakukan terkait informasi yang dibutuhkan.

Keterampilan literasi informasi terdiri dari, bagaimana cara menemukan, mengakses, menafsirkan, menganalisis, mengelola, membuat, menyimpan, dan membagikan informasi (CILIP: The Library and Information Association, 2018). Literasi informasi didefinisikan sebagai sebuah keterampilan berpikir kritis serta pembuatan penilaian yang berimbang tentang informasi yang ditemukan dan digunakan (Prado \& Marzal, 2013). Adapun literasi informasi disebut sebagai seperangkat kemampuan yang selaras. Di mana kemampuan ini memiliki cakupan dalam penemuan informasi secara reflektif, pemahaman bagaimana informasi dibuat dan diberikan penilaian, menggunakan informasi dalam sebuah pengetahuan yang baru, dan turut aktif secara etis dalam komunitas pembelajaran (Tewell, 2015).

Literasi informasi merupakan seperangkat kemampuan yang mengharuskan individu mengenali kapan informasi dibutuhkan dan memiliki kemampuan menemukan informasi, mengevaluasi informasi yang sudah didapatkan, dan menggunakan informasi yang didapatkan secara efektif. Keterampilan literasi informasi penting dimiliki masyarakat karena saat ini banyak perubahan dalam kehidupan, khususnya kehidupan profesional seseorang (Koltay, Špiranec, \& Karvalics, 2015). Setiap individu diharapkan beradaptasi dan mengatasi kemajuan teknologi yang pesat.
Individu dapat mengurangi pengoperasian teknologi di sehari-hari dan memiliki kemampuan memecahkan masalah secara proaktif. Untuk itu, individu memerlukan keterampilan literasi informasi dalam mengikuti perubahan dalam kehidupan, karier, dan pekerjaan.

Era informasi telah berkembang dan berdampingan dengan era digital sehingga memerlukan diskusi mengenai perkembangan literasi informasi. Hal ini memengaruhi kebutuhan informasi melalui sumber daya digital (Becker, 2018). Individu yang menggunakan informasi secara benar dikatakan sebagai individu yang literat. Hal ini dapat meningkatkan kualitas hidup dan meningkatkan hidup orang banyak. Selain itu, individu yang terlatih menerapkan sumber daya informasi dalam pekerjaan disebut sebagai individu yang literat. Setiap individu telah mempelajari teknik dan keterampilan dalam memanfaatkan berbagai alat informasi dan menjadikannya sebagai sumber utama dalam penyelesaian masalah (Nurfadhilah, Agustini, \& Sumiati, 2012).

Individu yang literat didefiniskan sebagai orang yang memiliki kemampuan dalam menentukan sejauh mana informasi dibutuhkan, cara akses informasi yang efektif dan efisien, evaluasi informasi dan sumber secara kritis, memasukkan informasi yang dipilih ke dalam basis pengetahuan seseorang, menggunakan informasi secara efektif untuk mencapai tujuan tertentu, dan memahami masalah ekonomi, hukum, sosial di sekitar penggunaan informasi, mengakses dan menggunakan informasi secara etis dan legal (American Library Association, 2020). Selain itu, literasi informasi saat ini tidak terbatas pada bahan pustaka saja. Literasi 
informasi telah masuk dalam ranah media sosial. Portal media sosial telah ada dan menciptakan ekosistem informasi yang dihuni hiruk-pikuk pendapat, informasi benar dan salah, jumlah data yang belum pernah terjadi sebelumnya, dan memuat banyak topik (American Library Association, 2020).

Para pembuat kebijakan dan industri media sosial bergulat dengan tantangan dalam membatasi berita palsu, disinformasi, pidato berisikan kebencian, dan bidang kedokteran yang dihadapkan pada penyebaran informasi kesehatan yang salah, tidak akurat, atau tidak lengkap (Chou, Oh, \& Klein, 2018). Sejalan dengan hal yang dijelaskan sebelumnya, dapat dilihat bahwa literasi informasi bukanlah hal khusus yang hanya dimiliki perpustakaan saja, namun literasi informasi sebagai masalah kritis dalam kehidupan profesional, karier, dan kesehatan. Untuk itu, individu perlu mengetahui bagaimana cara mengidentifikasi dan mencari informasi kesehatan yang kredibel (Butler, 2019). Hal ini karena literasi kesehatan memainkan peran kunci dalam promosi kesehatan (Suka et al., 2015).

Konsep literasi informasi kesehatan mengacu pada faktor pribadi dan hubungan yang memengaruhi kemampuan seseorang dalam memperoleh informasi, memahami dan menggunakan informasi pelayanan kesehatan, dan kesehatan secara keseluruhan. Selama bertahun-tahun, upaya pengembangan konsep literasi informasi kesehatan belum berkembang dengan baik dan wacana pengembangan literasi kesehatan masyarakat sering kali jauh berbeda (Batterham, Hawkins, Collins, Buchbinder, \& Osborne, 2016).

Sumber daya informasi digital dan jumlah pengguna media yang meningkat membuat internet sebagai sumber daya yang tak ternilai dalam media penyebaran informasi kesehatan pada masyarakat umum (Prabhu et al., 2016). Literasi informasi kesehatan sangat dibutuhkan masyarakat, namun sebagian orang menganggap informasi adalah berita, informasi sebagai fakta, dan informasi dianggap sebagai sebuah data (Anunobi \& Udem, 2014). Literasi informasi kesehatan masih dikaitkan dengan hasil kesehatan yang buruk dan penggunaan pelayanan kesehatan yang kurang optimal (Trivedi, Kossakowski, Berneis, Tischler, \& Daluiski, 2016). Individu dalam mencari informasi kesehatan sendiri membutuhkan tiga faktor utama, di antaranya kesadaran, akses, dan penilaian (Hirvonen et al., 2020), yang semuanya terdapat dalam keahlian literasi informasi.

Penelitian mengenai keterampilan literasi informasi kesehatan telah diteliti Lawless, Toronto, and Grammatica (2016). Penelitian terdahulu ini memiliki hubungan dengan penelitian yang peneliti teliti yaitu dalam konsep literasi informasi kesehatan yang berasal dari bidang perpustakaan dan ilmu informasi yang menekankan peran individu sebagai subjek aktif dalam perolehan informasi, bukan sebagai objek kegiatan. Lawless et al., (2016) memiliki persamaan dengan penelitian ini dalam konsep literasi kesehatan yang fokus pada penemuan informasi kesehatan. Adapun perbedaannya terdapat pada sarana dalam pencarian informasi kesehatan. Penelitian ini dibandingkan penelitian lain menghadirkan informasi kesehatan melalui media sosial. Untuk itu, media sosial sebagai kebaruan dalam penelitian ini.

Fokus penelitian literasi kesehatan sekarang bergeser dalam menganalisis cara individu mengakses, memahami, menilai, 
dan menerapkan informasi kesehatan dalam berbagai situasi. Namun, konseptualisasi yang lebih luas mengenai literasi kesehatan telah muncul dan konsep tersebut dipandang memerlukan pengetahuan, motivasi, dan kompetensi masyarakat dalam mengakses, memahami, menilai, dan menerapkan informasi kesehatan. Hal ini digunakan dalam membuat penilaian dan keputusan kehidupan sehari-hari mengenai perawatan kesehatan, pencegahan penyakit dan promosi kesehatan untuk menjaga atau meningkatkan kualitas hidup selama masa hidup (Sørensen et al., 2012).

Individu dapat memandang pesan kesehatan sebagai sebuah pesan yang berkualitas tinggi, tetapi tidak disertai kepercayaan atas sumber informasi yang benar, contohnya sumber faktor eksternal dari pengalaman negatif sebelumnya. Dengan demikian, individu tersebut memutuskan untuk tidak bertindak berdasarkan informasi tersebut (Diviani, Van den Putte, Giani, \& Van Weert, 2015). Untuk itu, individu perlu lebih banyak memperhatikan masalah kualitas informasi kesehatan dalam jaringan dan khususnya kemampuan untuk mengevaluasi.

Berdasarkan paparan latar belakang masalah ini, maka penelitian ini bertujuan untuk mengetahui bagaimana keterampilan literasi informasi sebagai upaya pencegahan hoaks mengenai informasi kesehatan di media sosial melalui beberapa tahap, di antaranya: pengenalan informasi yang di butuhkan, kemampuan menemukan informasi, evaluasi informasi, dan penggunaan informasi secara efektif.

\section{METODE PENELITIAN}

Penelitian keterampilan literasi informasi sebagai upaya pencegahan hoaks mengenai informasi kesehatan di media sosial ini menggunakan pendekatan kualitatif melalui metode penelitian studi kasus. Pada umumnya penelitian kualitatif dapat digunakan untuk penelitian mengenai kehidupan sebuah masyarakat, sejarah, tingkah laku, konsep atau fenomena, masalah sosial, dan lain-lain (Batubara, 2017).

Adapun studi kasus merupakan studi yang mengeksplorasi suatu kasus secara mendalam, mengumpulkan informasi secara lengkap menggunakan berbagai prosedur pengumpulan data berdasarkan waktu yang telah ditentukan. Kasus ini dapat berupa suatu peristiwa, aktivitas, proses, dan program (Batubara, 2017). Studi kasus dipilih dalam penelitian ini untuk mendeskripsikan, membandingkan, mengevaluasi, dan memahami aspek yang berbeda dari masalah keterampilan literasi informasi masyarakat sebagai upaya pencegahan hoaks mengenai informasi kesehatan di media sosial.

Penelitian studi kasus didefinisikan sebagai metodologi yang fleksibel, menantang, dan paling umum digunakan dalam penelitian ilmu sosial (Prihatsanti, Suryanto, \& Hendriani, 2018). Peneliti dalam tahapan studi kasus yang dilakukan dalam penelitian ini yaitu mengembangkan pernyataan masalah dan pertanyaan penelitian, dan memilih kasus spesifik yang ingin difokuskan yaitu mengenai literasi informasi di media sosial. Studi kasus yang dikembangkan dalam penelitian ini berpotensi untuk memberikan wawasan baru atau tak 
terduga tentang literasi informasi kesehatan di masyarakat menggunakan media sosial, mengusulkan tindakan praktis untuk menyelesaikan masalah melalui upaya pencegahan hoaks, dan membuka arah baru untuk penelitian masa depan.

Peneliti memilih studi kasus memberikan beberapa keuntungan, yakni penelitian ini bersifat murah dan tidak memakan waktu karena subjek penelitian pada masyarakat yang menggunakan gadget. Selain itu, studi kasus menguntungkan ketika peneliti mempelajari populasi yang dinamis, yaitu penggunaan media sosial yang sulit ditindaklanjuti. Peneliti dalam menulis studi kasus, perlu menyatukan semua aspek yang relevan dalam memberikan gambaran selengkap mungkin dari subjek yang diteliti. Keunikan penelitian ini adalah peneliti mengambil dari maraknya masyarakat yang mencari informasi mengenai apapun, termasuk informasi tentang kesehatan yang mengandalkan media sosial.

Peneliti menggunakan purposive sampling dalam jenis penentuan sampel. Purposive sampling sebagai teknik pengambilan sampel dengan menentukan kriteria tertentu. Subjek pada penelitian ini berjumlah 15 orang sebagai pengguna media sosial yang mencari informasi kesehatan dengan rentang usia 20-45 tahun. Rentang usia ini dipilih sebagai usia yang produktif menurut Kementerian Kesehatan Republik Indonesia (2014), di mana usia yang sangat penting menjaga pola hidup sehat agar bisa tetap bugar dan minim risiko penyakit saat tua. Usia produktif pun masih sangat aktif dalam mencari informasi seputar kesehatan menggunakan media sosial.

$$
\text { Adapun objek penelitian pada }
$$

penelitian ini adalah keterampilan literasi informasi mengenai kesehatan. Objek penelitian ini dipilih karena tidak semua masyarakat terampil menggunakan media sosial. Untuk itu, objek penelitian hanya terfokus pada masyarakat usia produktif. Waktu penelitian dilakukan mulai dari Januari sampai dengan Juni 2020 di daerah Cikoang dan Sekeburuy, Ujung Berung, kota Bandung. Lokasi ini dipilih karena merupakan daerah padat penduduk dengan usia produktif.

Peneliti dalam teknik pengumpulan data melakukan wawancara dan observasi, observasi partisipan, dokumen tertulis, catatan resmi, catatan pribadi, dan gambar atau foto. Seluruh cara tersebut akan menghasilkan bukti atau data yang berbeda, yang selanjutnya akan memberikan pandangan yang berbeda pula mengenai fenomena yang diteliti. Berbagai pandangan itu akan melahirkan keluasan pengetahuan untuk memperoleh kebenaran handal. Adapun peneliti dalam teknik analisis data menggunakan empat tahapan, antara lain pengumpulan data, reduksi data sesuai tema penelitian, penyajian data, penarikan kesimpulan, dan verifikasi.

\section{HASIL DAN PEMBAHASAN}

Peneliti melakukan analisis data berdasarkan hasil wawancara terhadap kelompok informan pengguna media sosial yang mencari informasi tentang kesehatan. Setelah melalui proses wawancara dan analisis hasil, menghasilkan beberapa tema sebagai berikut. Tema pertama, keterampilan mengenai pengenalan informasi yang di butuhkan. Berita palsu atau hoaks memunculkan kekhawatiran yang memicu minat baru dalam berbagai bentuk literasi informasi. Istilah "berita palsu" atau hoaks 
merupakan informasi yang salah, sering kali sensasional, disebarluaskan sebagai kedok "berita". Profesional informasi dalam jurnalisme atau ilmu perpustakaan dan bidang lain percaya bahwa definisi berita palsu terlalu sempit. Berita palsu tidak mempertimbangkan faktor penting lainnya, termasuk perbedaan antara jenis konten, tujuan, dan sarana penyebaran (Jones-Jang, Mortensen, \& Liu, 2021).

Informasi palsu berkembang di segala aspek, termasuk aspek kesehatan. Informasi yang keliru mengenai kesehatan atau berita palsu bukan fenomena baru. Hal ini sudah terjadi dalam waktu yang lama, akarnya mungkin sudah setua pelayanan kesehatan itu sendiri (Waszak, Kasprzycka-Waszak, \& Kubanek, 2018). Pada era pra media, masalah ini berpusat pada hubungan pasien dokter dan konteksnya. Sesuai revolusi radio dan televisi, ada peningkatan eksponensial penggunaan internet secara global dan berbagai potensi bahaya yang dibawa ke tingkat yang sama sekali baru (Bode \& Vraga, 2018).

Sesuai rujukan ini, pengenalan informasi kesehatan yang dibutuhkan menjadi hal yang penting untuk dimiliki. Saat ini, diketahui bahwa ada peningkatan dramatis dalam pencarian informasi kesehatan secara daring oleh masyarakat. Informasi kesehatan daring perlu mendapatkan perhatian khusus. Ada penelitian konten situs website terkait kesehatan yang menyoroti informasi yang tidak akurat sehingga menimbulkan kekhawatiran tentang kualitas informasi kesehatan daring. Ketepatan informasi yang masih terbatas merupakan salah satu fitur khas internet. Siapa pun dapat memublikasikan informasi terkait kesehatan secara potensial.

Pencarian informasi kesehatan daring menimbulkan beberapa tantangan besar bagi pengguna informasi kesehatan. Pengguna dapat berperan aktif mengevaluasi sejumlah besar informasi kesehatan yang sering tidak diverifikasi di internet. Kesehatan masyarakat dihadapkan resiko paparan pasien terhadap informasi yang keliru dan menyesatkan. Fenomena ini dapat memengaruhi literasi kesehatan dan menyebarkan teori konspirasi medis. Hal tersebut dapat mengakibatkan perubahan perilaku dan memunculkan ancaman serius bagi kesehatan masyarakat.

Masyarakat dapat mengenali informasi yang dibutuhkan melalui identifikasi informasi sesuai kebutuhan pribadinya. Hal ini merupakan sesuatu yang jelas dan penting, tetapi seringkali dianggap remeh. Banyak orang yang secara keliru menganggap sudah cukup mengetahui informasi yang dibutuhkan kemudian melanjutkan pencarian informasi tersebut secara acak. Asumsi tersebut dapat membuang waktu berharga dalam mendapatkan informasi yang tidak lengkap, ketinggalan zaman, atau bahkan salah. Hal ini seperti yang dikemukakan informan $\mathrm{C}$, proses pengenalan informasi merupakan hal penting yang harus dimiliki sebelum mencari informasi yang dibutuhkan. Informan B juga mengemukakan pengalamannya yang salah menerima informasi dikarenakan tidak mengenali secara mendalam mengenai informasi yang dicarinya. Sejalan dengan itu, informan A menjelaskan bahwa pengenalan informasi ini penting di lakukan karena setiap topik informasi yang ada, terutama di media sosial, akan terus berkembang.

Informasi mengenai kesehatan yang tersedia memang sangat bervariasi. Secara umum, saat ini lebih banyak informasi 
kesehatan yang dapat diakses daripada sebelumnya. Untuk itu, aspek pengenalan informasi dibutuhkan dalam keterampilan literasi informasi sebagai pengembangan kebiasaan berpikir dan praktik dalam mencari informasi baru. Kemudian, pengguna dapat menyesuaikan diri mengenai pemahaman topik yang ditemukan. Kualitas informasi baru pun beragam, maka evaluasi merupakan elemen kunci dari literasi informasi. Pengguna yang dapat mengidentifikasi kebutuhan informasinya, maka kebutuhan informasi dirinya akan terpenuhi. Pengguna telah memahami bahwa informasi dan data baru akan terusmenerus diproduksi dan banyak dipelajari, seperti yang telah di jelaskan oleh informan.

Literasi informasi melibatkan pengembangan kebiasaan belajar sehingga informasi baru yang sedang dicari akan secara aktif terbaru setiap saat. Gagasan dan peluang tersebut diciptakan melalui penyelidikan atau pencarian informasi. Pengguna dapat mengidentifikasi kapan membutuhkan informasi. Pengguna dapat mengidentifikasi kurangnya pengetahuan dalam bidang subjek yang dicari melalui identifikasi lebih mendalam topik tersebut. Pengguna dapat mencari atau mempertanyakan, mendefinisikan, dan mengartikulasikan pengetahuan terkini tentang suatu topik. Pengenalan kebutuhan informasi dan data juga dilakukan untuk mencapai tujuan tertentu dan menentukan batasan atas kebutuhan informasi. Hal ini berarti bahwa ketika para pengguna media sosial telah mengenali informasi dengan baik untuk mendukung pencarian, pengguna dapat mengambil tanggung jawab pribadi dalam pencarian informasi dan mengelola waktu secara efektif untuk menyelesaikan pencarian. Pengenalan informasi ini pun dapat digunakan sebagai bahan evaluasi antar informasi yang didapatkan.

Tema kedua, kemampuan menemukan informasi. Kemampuan ini berarti dapat membangun strategi dalam pencarian informasi dan data yang sesuai dengan informasi yang dibutuhkan. Di mana pengguna dalam kemampuan pencarian informasi mewajibkan untuk memahami jenis media sosial yang di pilih, serta berbagai teknik pencarian di media sosial, seperti penggunaan kata kunci atau penggunaan tanda pagar untuk hasil yang lebih spesifik. Penggun dengan kemampuan menemukan informasi di media sosial akan memahami berbagai jenis dan karakteristik media sosial dari masing-masing media sosial tersebut, misalnya, Instagram, YouTube, Facebook, Blog, dan lainnya.

Media sosial sangat populer di berbagai kelompok usia, termasuk pada kelompok usia produktif. Situs jejaring sosial seperti Instagram, misalnya, termasuk media sosial populer yang digunakan mahasiswa. Meskipun tujuan utama menggunakan sosial situs jejaring sosial terkait sosialisasi, semakin banyak individu mendapatkan berita dari situs jejaring sosial. Situs media sharing seperti YouTube juga dikenal sebagai sumber berita penting (Kim \& Sin, 2014). Jika dilihat dengan saksama, maka kemampuan menemukan informasi yang benar merupakan hal yang harus diperhatikan untuk menghindari informasi hoaks dari media sosial.

Setelah mengenali informasi yang dibutuhkan, pengguna media sosial mencari media yang paling tepat dalam menemukan informasi. Hasil wawancara dengan informan D, di mana informan akan mencari informasi melalui Instagram, 
menurutnya Instagram telah menyediakan penjelasan secara umum dan cukup lengkap dari informasi yang dibutuhkan. Berbeda dengan informan $\mathrm{D}$, informan $\mathrm{E}$ dan $\mathrm{F}$ menyatakan lebih menyenangkan mencari informasi di media YouTube, karena media tersebut menyajikan informasi dalam bentuk video yang membuatnya lebih menarik. Sementara itu, informan $G$ menyatakan bahwa media Twitter lebih menyajikan informasi yang up-to-date.

Pemilihan media informasi dilakukan untuk memudahkan pengguna dalam proses identifikasi informasi tentang topik yang dibutuhkan. Media sosial adalah tempat pencarian informasi bagi mereka yang memiliki gambaran umum tentang suatu subjek yang diminati. Media sosial memiliki informasi dalam kategori luas, seperti keuangan, olahraga, atau perjalanan. Anggap saja mereka sebagai katalog kartu raksasa. Para pengguna memulai dengan kategori di atas kemudian bergerak ke bawah melalui sub kategori untuk mempersempit pencarian sampai menemukan informasi yang di butuhkan. Media sosial merupakan salah satu sarana terbaik untuk menemukan informasi dengan menggunakan kata kunci atau frasa untuk menentukan informasi yang relevan.

Tema ketiga, keterampilan mengevaluasi informasi. Evaluasi informasi berarti pengguna yang mencari informasi mengenai kesehatan dapat mengevaluasi informasi dan data yang sudah didapatkan sesuai kualitas dan relevansi informasi yang dibutuhkan. Dalam tinjauan sistematis, Moorhead et al. (2013) mengidentifikasi beberapa manfaat media sosial untuk komunikasi terkait kesehatan, termasuk peningkatan aksesibilitas informasi kesehatan, potensi peningkatan dukungan emosional, dan kemungkinan peningkatan pengawasan kesehatan masyarakat. Selain itu, media sosial dapat digunakan secara efektif untuk melibatkan publik dan mengkomunikasikan pesan yang berhubungan dengan kesehatan. Selama pandemi H1N1 2009, misalnya, Centers for Disease Control (CDC) menggunakan Facebook untuk mengedukasi masyarakat tentang penyakit dan pentingnya vaksinasi (Kass-Hout \& Alhinnawi, 2013). Sayangnya, platform media sosial dan situs internet lainnya dapat menyebarkan informasi yang tidak akurat atau menyesatkan. Hal ini yang menjadikan tahapan evaluasi perlu ada dalam keterampilan literasi informasi.

Informan $\mathrm{H}$ menyatakan bahwa evaluasi informasi ini penting dilakukan agar informasi yang didapatkan dapat dipercaya. Informan I melakukan engevaluasi informasi mengenai kesehatan kulit wajahnya langsung dari media Instagram dokter kulit yang informan ikuti selama 2 tahun terakhir. Kredibilitas dokter tersebut menjadikan informan I percaya akan kebenaran informasi yang disampaikannya. Sejalan dengan informan $\mathrm{H}$, informan $\mathrm{O}$ menambahkan bahwa evaluasi informasi dilakukan untuk mengontrol kualitas informasi. Informan M menjelaskan bahwa proses evaluasi informasi yang dilakukan biasanya menggunakan bantuan Hashtag sebagai salah satu strategi agar informasi yang muncul hanya informasi yang sesuai.

Fakta dalam beberapa kasus dapat digabungkan dengan setengah kebenaran untuk menghasilkan "campuran informasi". Akibatnya, lingkungan internet yang tidak diatur mendorong spekulasi, rumor, dan ketidak percayaan pada lembaga ilmiah atau medis. 
Informasi daring diterbitkan untuk berbagai tujuan, di antaranya mendorong pembaca untuk mempercayai, menginformasikan, menghibur, menginspirasi, mengajar, menjelaskan, menipu, dan bahkan membujuk. pada kegiatan proses evaluasi informasi, pengguna akan dapat membedakan antara sumber informasi yang sesuai dengan informasi yang berbeda dari informasi dibutuhkan. Pengguna dapat menilai kredibilitas data yang dikumpulkan. Untuk itu, pengguna dalam proses evaluasi harus membaca secara kritis, mengidentifikasi poin dan argumen utama, dan menghubungkan informasi yang ditemukan melalui strategi pencarian.

Media sosial telah mendapatkan kredibilitas sebagai salah satu jenis sumber daya informasi, namun pengguna harus mengetahui siapa yang telah memberikan informasi di media sosial tersebut. Pengguna harus mengetahui apakah akunnya resmi atau tidak, apakah orang tersebut ahli di bidangnya, atau tidak agar terhindar dari informasi yang menyesatkan. Hal ini dinamakan evaluasi informasi. Pengguna untuk mengevaluasi informasi, harus mengetahui siapa penulis informasi tersebut dan kualifikasi yang dimiliki mengenai topik kesehatan tersebut. Pengguna ada baiknya mengetahui latar belakang pendidikan, pengalaman, pekerjaan atau publikasi lain yang relevan dengan tulisan yang diterbitkan tersebut. Kegiatan proses evaluasi informasi terdapat penilaian secara kritis dan evaluasi dari temuan informasi. Hal ini menandakan bahwa pengguna sudah mengetahui kapan harus berhenti mencari informasi.

Tema keterampilan keempat, penggunaan informasi yang telah didapatkan secara efektif. Keempat keterampilan yang telah dijelaskan masuk ke dalam literasi informasi. Literasi informasi adalah seperangkat keterampilan yang mengharuskan individu untuk mengenali kapan informasi dibutuhkan dan memiliki kemampuan untuk menemukan, mengevaluasi, dan menggunakan informasi yang dibutuhkan secara efektif, (American Library Association, 2020). Penggunaan informasi secara efektif sangat penting dalam masyarakat untuk pemecahan masalah, pengambilan keputusan, dan penelitian. Untuk itu, keterampilan penggunaan informasi yang telah didapatkan harus dilakukan dengan efektif.

Pengguna media sosial menggunakan informasi untuk mengurangi ketidakpastian. Semakin banyak informasi yang diberikan, maka informasi yang tidak pasti dapat dikurangi. Pengguna menggunakan informasi kesehatan untuk kebutuhan diri pengguna sendiri. Hal ini sejalan yang dikemukakan informan J dan $\mathrm{K}$ yang menyebutkan bahwa informan mencari informasi tentang pola diet sehat untuk digunakan oleh dirinya sendiri. Informan L menambahkan apabila mencari informasi secara sembarangan, informasi tidak dapat digunakan secara efektif dan tidak akan memberikan hasil yang maksimal dalam pola dietnya.

Pengguna melalui teknologi dapat mengakses informasi sangat mudah. Para pencari informasi akan memanfaatkan teknologi sampai tingkat tertentu dan menggunakan informasi untuk kepentingan sendiri. Informasi yang digunakan secara efektif berkaitan dengan pemahaman sumber informasi yang dipilih dan cara penerapan informasi. Pengguna dalam menggunakan informasi 
akan mengetahui bahwa informasi tidak hanya dikumpulkan dan dilupakan begitu saja. Informasi yang bernilai adalah informasi yang dapat digunakan dan memberikan manfaat bagi pengguna lain. Pengguna akan bertanggung jawab saat menggunakan informasi yang ditemukannya. Apalagi, informasi banyak disebarkan pada masyarakat luas. Untuk itu, dalam menyebarkan kembali informasi yang telah diterima harus memperhatikan secara etika dan legal. Hal ini akan membantu pengguna dalam menghindari berita palsu atau hoaks.

\section{SIMPULAN}

Berdasarkan hasil penelitian ini, literasi informasi tentang kesehatan pada masyarakat dengan memanfaatkan media sosial memiliki beberapa simpulan. Pertama, masyarakat mengidentifikasi atau mengenali kapan informasi tersebut dibutuhkan. Pengguna dalam proses pengenalan informasi memahami kapan harus mencari informasi dan mengetahui informasi apa yang akan dicari. Kedua, pengguna memiliki kemampuan dalam menemukan informasi melalui berbagai cara, di antaranya memilih portal media massa yang mudah digunakan atau media massa yang memberikan penjelasan lebih rinci. Pengguna pun mencari informasi secara spesifik menggunakan kata kunci, tanda pagar atau hashtag. Ketiga, pengguna mengevaluasi informasi yang sudah ditemukan, seperti pengguna mengetahui siapa pembuat informasi tersebut? Siapa yang menyebarkan informasi tersebut? Apakah akun media sosialnya terpercaya? Apakah kepakarannya sudah sesuai dengan informasi yang dibutuhkan? Hal ini dilakukan sebagai tolak ukur informasi yang valid dan dapat mencegah hoaks atau informasi palsu. Keempat, pengguna menggunakan informasi yang telah didapatkan secara efektif. Pengguna menggunakan informasi untuk diri sendiri, maka pengguna memilih informasi sesuai kebutuhan. Pengguna akan lebih selektif dalam menggunakan informasi kesehatan agar tidak terjadi kesalahan yang diakibatkan hoaks. Pengguna dalam penelitian ini telah mempraktikkan keterampilan literasi informasi di aktivitas kesehariannya sebagai upaya pencegahan hoaks di media sosial. Rekomendasi untuk penelitian selanjutnya adalah penelitian dapat dikhususkan pada pencarian informasi kesehatan di satu media sosial karena setiap media sosial memiliki keunikan dan kekhasan masing-masing sehingga bisa digali lebih mendalam dengan mengusung keunikan media sosial yang dibahas.

\section{DAFTAR PUSTAKA}

American Library Association. (2020). Information literacy. American Library Association. Retrieved from https:/ / literacy.ala.org/informationliteracy/

Anunobi, C., \& Udem, O. K. (2014). Information literacy competencies: A conceptual analysis. Journal of Applied Information Science and Technology, 7(2), 64-80. Retrieved from https://www.jaistonline.org/Anunob iUdem_vol7no2_2k14.pdf

Batterham, R. W., Hawkins, M., Collins, P. A., Buchbinder, R., \& Osborne, R. H. (2016). Health literacy: Applying current concepts to improve health services and reduce health inequalities. Public Health, 132(3), 312.

https:// doi.org/10.1016/j.puhe.2016. 01.001 
Batubara, J. (2017). Paradigma penelitian kualitatif dan filsafat ilmu pengetahuan dalam konseling. Jurnal Fokus Konseling, 3(2), 95-107. https:/ / doi.org/10.26638/jfk.387.2099

Becker, B. W. (2018). Information literacy in the digital age: Myths and principles of digital literacy. School of Information Student Research Journal, $7(2)$, 1-8. https:/ / doi.org/10.31979/25752499.070202

Bode, L., \& Vraga, E. K. (2018). See something, say something: Correction of global health misinformation on social media. Health Communication, 33(9), 1131-1140. https:/ / doi.org/10.1080/10410236.20 17.1331312

Butler, R. (2019). Health information seeking behaviour: The librarian's role in supporting digital and health literacy. Health Information $\mathcal{E}$ Libraries Journal, 36(3), 278-282. https:/ / doi.org/10.1111/hir.12278

Chou, W.-Y. S., Oh, A., \& Klein, W. M. P. (2018). Addressing health-related misinformation on social media. JAMA， 320(23), 2417-2418. https://doi.org/10.1001/jama.2018.16 865

CILIP: The Library and Information Association. (2018). CILIP definition of information literacy 2018. Information Literacy Group. Retrieved from https://infolit.org.uk/ILdefinitionCI LIP2018.pdf

Diviani, N., Van den Putte, B. , Giani, S., \& Van Weert, J. C. (2015). Low health literacy and evaluation of online health information: A systematic review of the literature. Journal of Medical Internet Research, 17(5), 1-17. https:/ / doi.org/10.2196/jmir.4018
Hirvonen, N., Enwald, H., Mayer, A.-K., Korpelainen, R., Pyky, R., Salonurmi, T., ... Huotari, M.-L. (2020). Screening everyday health information literacy among four populations. Health Information $\mathcal{E}$ Libraries Journal, 37(3), 192-203.

https:/ / doi.org/10.1111/hir.12304

Jones-Jang, S. M., Mortensen, T., \& Liu, J. (2021). Does media literacy help identification of fake news? Information literacy helps, but other literacies don't. American Behavioral Scientist, $\quad 65(2), \quad 371-388$. https:/ / doi.org/10.1177\%2F00027642 19869406

Kass-Hout, T. A., \& Alhinnawi, H. (2013). Social media in public health. British Medical Bulletin, 108(1), 5-24. https://doi.org/10.1093/bmb/ldt028

Kementerian Kesehatan Republik Indonesia. (2014). Kamus PUSDATIN. Pusat Data Dan Informasi Kementerian Kesehatan Republik Indonesia. Retrieved from https:/ / pusdatin.kemkes.go.id/folde $\mathrm{r} /$ view/full-content/structurekamus.html

Kim, K.-S., \& Sin, S.-C. J. (2014). Use of social media in different contexts of information seeking: Effects of sex and problem solving style. Proceedings of ISIC: The Information Behaviour Conference, 1-10. Retrieved from http:/ /informationr.net/ir/201/isic2/isic24.html\#.YNxfLugzbce

Koltay, T., Špiranec, S., \& Karvalics, L. Z. (2015). The shift of information literacy towards research 2.0. The Journal of Academic Librarianship, 41(1), 87-93.

https://doi.org/10.1016/j.acalib.2014. 11.001

Lawless, J., Toronto, C. E., \& Grammatica, 
G. L. (2016). Health literacy and information literacy: A concept comparison. Reference Services Review, 44(2), 144-162. https://doi.org/10.1108/RSR-022016-0013

Mackey, T. P., \& Jacobson, T. E. (2014). Metaliteracy: Reinventing information literacy to empower learners. London: Facet Publishing.

Moorhead, S. A., Hazlett, D. E., Harrison, L., Carroll, J. K., Irwin, A., \& Hoving, C. (2013). A new dimension of health care: Systematic review of the uses, benefits, and limitations of social media for health communication. Journal of Medical Internet Research, 15(4), 1-17. https:// doi.org/10.2196/jmir.1933

Naik, M. M., \& P. (2014). Importance of information literacy. International Journal of Digital Library Services (IJODLS), 4(3), 92-100. Retrieved from http:/ /www.ijodls.in/uploads/3/6/ 0/3/3603729/9434.pdf

Nurfadhilah, R., Agustini, N., \& Sumiati, T. (2012). Hubungan kemampuan literasi informasi anggota ikatan pustakawan pelajar dengan prestasi belajar di sekolah. Students E-Journal, 1(1), 1-15. Retrieved from https://jurnal.unpad.ac.id/ejournal/ article/view/1683/pdf_11

Prabhu, A. V., Gupta, R., Kim, C., Kashkoush, A., Hansberry, D. R., Agarwal, N., \& Koch, E. (2016). Patient education materials in dermatology. JAMA Dermatology, 152(8), 946-947. https:// doi.org/10.1001/jamadermat ol.2016.1135

Prado, J. C., \& Marzal, M. Á. (2013). Incorporating data literacy into information literacy programs: Core competencies and contents. Libri, 63(2), 123-134. https:/ / doi.org/10.1515/libri-20130010

Prihatsanti, U., Suryanto, \& Hendriani, W. (2018). Menggunakan studi kasus sebagai metode ilmiah dalam psikologi. Buletin Psikologi, 26(2), 126136.

https:/ / doi.org/10.22146/buletinpsik ologi.38895

Sørensen, K., Van den Broucke, S., Fullam, J., Doyle, G., Pelikan, J., Slonska, Z., \& Brand, H. (2012). Health literacy and public health: A systematic review and integration of definitions and models. BMC Public Health, 12(80), 113. https://doi.org/10.1186/14712458-12-80

Suka, M., Odajima, T., Okamoto, M., Sumitani, M., Igarashi, A., Ishikawa, H., .... Sugimori, H. (2015). Relationship between health literacy, health information access, health behavior, and health status in Japanese people. Patient Education and Counseling, 98(5), 660-668. https:// doi.org/10.1016/j.pec.2015.02 .013

Tewell, E. (2015). A decade of critical information literacy: A review of the literature. Communications in Information Literacy, 9(1), 24-43. https:// doi.org/10.15760/comminfoli t.2015.9.1.174

Trivedi, N., Kossakowski, T., Berneis, M., Tischler, D. H., \& Daluiski, A. (2016). Evaluation of patient information posters directing patients to access a health information website. JAMA Surgery, 151(9), 880-881. https:// doi.org/10.1001/jamasurg.20 16.1235

Waszak, P. M., Kasprzycka-Waszak, W., \& 
Kubanek, A. (2018). The spread of medical fake news in social mediaThe pilot quantitative study. Health
Policy and Technology, 7(2), 115-118. https:/ / doi.org/10.1016/j.hlpt.2018.0 3.002 


\section{DAFTAR TABEL}

Tabel 1

Informan penelitian kelompok masyarakat usia produktif pengguna media sosial

\begin{tabular}{lllll}
\hline No & Inisial & Jenis kelamin & Usia & Pekerjaan \\
\hline 1 & A & L & 22 & Mahasiswa \\
2 & B & P & 20 & Mahasiswa \\
3 & C & P & 25 & Wirausaha \\
4 & D & L & 30 & Swasta \\
5 & E & L & 32 & PNS \\
6 & F & P & 33 & Wirausaha \\
7 & G & P & 33 & PNS \\
8 & H & P & 35 & Swasta \\
9 & I & P & 27 & Wirausaha \\
10 & J & L & 29 & Swasta \\
11 & K & L & 30 & Wirausaha \\
12 & L & P & 31 & PNS \\
13 & M & P & 33 & Swasta \\
14 & N & P & 28 & PNS \\
15 & O & L & 25 & Swasta \\
\hline
\end{tabular}

Sumber: Hasil penelitian, 2018 